\title{
PART 4
}

\section{ASTRONOMER'S HANDBOOK}




\title{
ASTRONOMER'S HANDBOOK
}

The Astronomer's Handbook (IAU Transactions Vol. XIIC, edited by J.-C. Pecker in 1966) contains many documents of permanent value. Only those parts which changed after the XIIIth General Assembly will be given here in the form of supplements. The numbering of paragraphs in XIIC will be adhered to in order to facilitate the reference from one volume to the other.

The reader is referred to the IAU Transactions Vol. XIIC in particular in all matters relating to the Style Book (p. 55 in French, p. 101 in English), to the Organization of Symposia and Colloquia (p. 129), and to the Statutes and By-laws (p. 138).

\section{PART 1 OF ASTRONOMER'S HANDBOOK}

\author{
I. SHORT HISTORY OF THE \\ INTERNATIONAL ASTRONOMICAL UNION
}

A, B, C no change against Trans. IAU, XIIC, 3.

D. Table 2 should be supplemented by the following data:

\begin{tabular}{cc} 
XIIIth General Assembly, 1967, Prague (Czechoslovakia) \\
Members of the Union (after the G. A.) & 2009 \\
Participants (788 Members) & 1835 \\
Number of Commissions & 38 \\
Volumes of Transactions A & 1156 pages \\
\multicolumn{1}{c}{ B } & 319 pages \\
Highlights 1967 & 558 pages \\
President: O. Heckmann & $1967-1970$ \\
General Secretary: L. Perek & $1967-1970$ \\
Assistant General Secretary: C. de Jager & $1967-1970$ \\
Vice-Presidents: W. Fricke & $1964-1967$ \\
W. N. Christiansen & $1964-1970$ \\
M. K. Vainu Bappu & $1967-1973$ \\
L. Gratton & $1967-1973$ \\
J. Sahade & $1967-1973$
\end{tabular}

\section{ADMINISTRATION AND FINANCES OF THE UNION}

\section{A. ADMINISTRATION}

The address of the Secretariat is

International Astronomical Union

Czechoslovak Academy of Sciences

Budečská 6

PRAHA 2

Czechoslovakia. 